\title{
PELATIHAN PENULISAN BERITA UNTUK SISWA SMA NEGERI 16 PEKANBARU
}

\author{
Mohd. Kafrawi*, Evizariza**, R.Syamsidar*** \\ FIB Universitas Lancang Kuning \\ Hangkaf74@yahoo.com*, evizariza@yahoo.com**, \\ rajasyamsidar610@yahoo.com***
}

\begin{abstract}
Abstrak
Di zaman modern ini ditandai dengan ditemukan teknologi canggih, manusia sangat cepat dan sangat memerlukan aksis berita, sehingga segala peristiwa yang terjadi dapat diketahui. Kenyataan ini memerlukan para penulis berita atau jurnalis yang memiliki kemampuan menulis berita yang mahir. Generasi muda, dalam hal ini, siswa-siswa SMA merupakan usia yang sangat potensial untuk dilatih menulis berita yang baik dan benar. Dengan pelatihan menulis berita, paling tidak siswa SMA dapat mengenal lebih dekat apa itu berita dan sekaligus dapat mempraktekkan menulis berita yang baik dan benar.
\end{abstract}

Kata Kunci: Berita, Menulis, Siswa

\begin{abstract}
In modern times, this is marked by the discovery of sophisticated technology, humans are very fast and desperately need the news axis, so that all events that occur can be known. This fact requires news writers or journalists who have proficient news writing skills. The young generation, in this case, high school students are of a very potential age to be trained to write good and true news. With news writing training, at least high school students can get to know what news is more closely and at the same time be able to practice writing good and true news.
\end{abstract}

Keywords: News, Writing, Students

PENDAHULUAN

Sebagaimana keterampilan

menulis lainnya, menulis berita

merupakan bagian penting dalam

mengkhabarkan peristiwa kepada

khalayak ramai. Banyak manfaat dari

menulis. Beberapa diantara manfaat tersebut menurut Akhadiah dkk (1998:

1-2) adalah membantu kita mengenal kemampuan dan potensi diri, mengembangkan berbagai gagasan, belajar mengorganisasikan gagasan secara sistematik dan dapat mengungkapkannya secara tersurat, membuat kita dapat meninjau serta menilai gagasan kita sendiri secara Pendidikan 729 
objektif, mendorong kita belajar secara aktif, belajar menganalisis serta membiasakan kita berpikir dan berbahasa secara tertib.

Dari banyak manfaat tersebut salah satu poin utamanya adalah bahwa menulis erat kaitannya dengan pengembangan pikiran dan penyampaian peristiwa. Pelajar sebagai agen of change dan calon cendekia muda semestinya memang harus aktif dalam menulis. Lewat tulisan, pelajar dapat menyampaikan gagasan-gagasan, pikiran serta pengetahuannya sekaligus dapat menyampaikan peristiwa kepada orang banyak, sehingga bisa dibaca oleh khalayak ramai. Namun, persoalannya banyak pelajar yang kurang mampu menulis dengan baik. Indikasi ini bisa ditemukan dari kurangnya penulis muda Riau yang muncul diberbagai media massa, baik cetak maupun online. Padahal dengan menulis terbuka lowongan pekerjaan yang mampu meningkatkan taraf ekonomi.

Salah satu penyebab dari persoalan ini adalah kekurangpahaman pelajar tentang aktivitas menulis. Selain itu masih kurangnya kurikulum di sekolah dalam mendalami ilmu menulis, khususnya menulis berita, sehingga pelajar sangat minin bersentuhan dengan dunia tulis menulis. Tentu saja, kurangnya bersentuhan dengan dunia menulis dan praktiknya di sekolah menyebabkan pelajar kurang tertarik, bahkan cenderung tidak menyukai menulis, khususnya menulis berita.

Berdasarkan kondisi tersebut maka kami merasa perlu untuk mengadakan pelatihan menulis, dalam hal menulis berita, yang ditujukan pada pelajar SMA. Pelajar sebagai objek sasaran dibatasi hanya pada pelajar SMA Negeri 16 Pekanbaru. Pembatasan ini lebih karena alasan keterbatasan kemampuan serta pengefektifan capaian pelatihan.

\section{METODE PELAKSANAAN}

Kegiatan $\mathrm{I}_{\mathrm{b}} \mathrm{m}$ dilakukan kepada pelajar SMA Negeri 16 Pekanbaru. Jumlah pelajar yang akan mengikuti pelatihan ini 30 orang. Pelaksanaan kegiatan meliputi beberapa tahap sebagai berikut.

1. Pelatihan mengetahui definisi berita

Pada tahap ini, tim melakukan transfer informasi mengenai definisi berita. Pada tahap ini juga tim memberikan pemahaman tentang pengertian berbagai bentuk berita dengan membaca berita-berita yang

Pendidikan 730 
ada di media massa, baik itu cetak maupun online.

Materi yang disampaikan pada tahap ini adalah:

- Definisi berita

- Mengenalkan bentuk-bentuk berita

- Peralatan yang diperlukan pada tahap ini adalah:

- Berita di media cetak

- Lembar Kerja

2. Pelatihan mengetahui ciri dan bentuk berita

Pada tahap ini, tim melakukan transfer informasi mengenai ciri dan bentuk berita. Materi yang disampaikan pada tahap ini adalah:

\section{- Ciri berita}

- Bentuk-bentuk berita

Peralatan yang dibutuhkan pada tahap ini adalah:

- Contoh berita

- Lembar Kerja

3. Pelatihan menghasilkan karya tulis, khususnya berita

Pada tahap ini, tim melakukan transfer informasi mengenai cara menulis berita. Tahap ini adalah tahap praktik. Masingmasing pelajar ditugaskan untuk membuat berita. Setelah itu dilakukan evaluasi bersama atas tulisan yang telah mereka buat.

Foto Kegiatan Pengabdian Menulis Berita di SMA Negeri 16 Pekanbaru

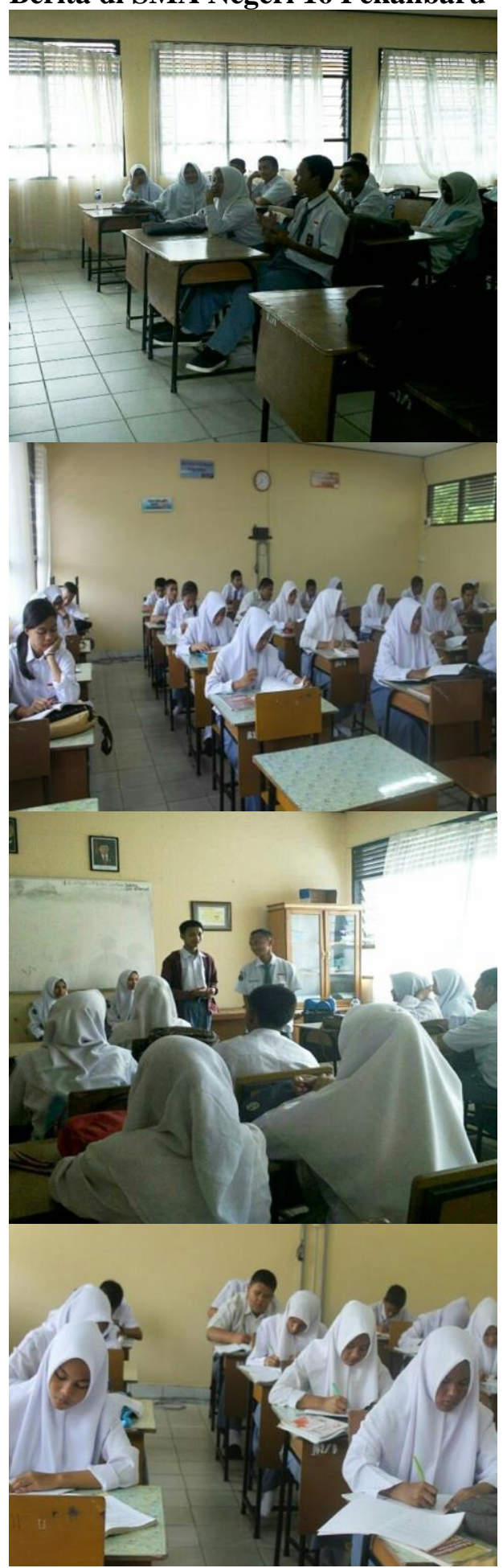

Pendidikan 731 
HASIL DAN LUARAN YANG

DICAPAI

\section{Hasil yang Dicapai}

Kegiatan pelatihan dilaksanakan pada tanggal 17 Juni 2019, pukul 08.00-12.30 WIB. Pelaksanaan kegiatan bertempat di ruang kelas SMA Negeri 16 Pekanbaru, Jalan Pramuka, Rumbai Pesisir, Pekanbaru.

Kegiatan pelatihan ini menunjukan hasil yang bagus bagi peserta, baik dari sisi kuantitatif maupun kualitatif. Dari sisi kuantitatif menunjukan jumlah peserta yang hadir berjumlah 30 orang, sesuai dengan target. Sisi kuantitatif menunjukan bahwa peserta pelatihan memiliki pemahaman mengenai fungsi dan manfaat menulis berita. Selain itu, mereka sudah memahami tentang berita, namun dalam praktek menulis belum mengetahui secara mendalam.

Selama pelatihan, peserta juga diberikan pre-test dan post-test untuk mengukur pemahaman dan kepuasan terkait pelatihan ini, berikut tabelnya:

\begin{tabular}{|c|c|c|c|c|}
\hline \multicolumn{5}{|c|}{ PRETEST } \\
\hline $\mathbf{N}$ & Topik Test & Ya & $\begin{array}{c}\text { Tida } \\
\mathbf{k}\end{array}$ & $\begin{array}{l}\text { Ragu } \\
\text {-ragu }\end{array}$ \\
\hline 1 & $\begin{array}{l}\text { Pengenalan } \\
\text { berita }\end{array}$ & 30 & 0 & 0 \\
\hline 2 & $\begin{array}{l}\text { Pernah } \\
\text { menulis } \\
\text { berita }\end{array}$ & 5 & 25 & 0 \\
\hline 3 & $\begin{array}{l}\text { Kemauan } \\
\text { belajar } \\
\text { menulis }\end{array}$ & 30 & 0 & 0 \\
\hline 4 & $\begin{array}{l}\text { Keuntunga } \\
\mathrm{n} \text { menulis } \\
\text { berita }\end{array}$ & 10 & 20 & 0 \\
\hline 5 & $\begin{array}{rr}\text { Keuntunga } \\
\text { a. } & \text { Mer } \\
& \text { kan } \\
\text { b. } & \text { Bis } \\
& \text { yan } \\
\text { c. } & \text { Bisa } \\
\text { d. } & \text { Seb } \\
& \text { mer } \\
\text { e. Dap } \\
\text { f. Mer } \\
\\
\text { yan } \\
\text { sep } \\
\text { mas } \\
\text { ceta }\end{array}$ & $\begin{array}{l}\text { nenu } \\
\text { posti } \\
\text { dlisan } \\
\text { men } \\
\text { ingin } \\
\text { mena } \\
\text { gai } \\
\text { abark } \\
\text { tija } \\
\text { anfaa } \\
\text { seda } \\
\text { ti } ~ \\
\text { on }\end{array}$ & $\begin{array}{l}\text { berita } \\
\text { /mem } \\
\text { erben } \\
\text { kspres } \\
\text { isamp } \\
\text { bah w } \\
\text { ajang } \\
\text { n kegi } \\
\text { kan us } \\
\text { an } \\
\text { g berl } \\
\text { miliki } \\
\text { he ata }\end{array}$ & $\begin{array}{l}\text { likasi } \\
\text { berita } \\
\text { an apa } \\
\text { an } \\
\text { asan } \\
\text { bisnis, } \\
\text { n } \\
\text { a } \\
\text { nologi } \\
\text { nbang, } \\
\text { media } \\
\text { media }\end{array}$ \\
\hline
\end{tabular}

Pendidikan 732 
Berdasarkan tabel mengenai pretest di atas, dapat diuraikan bahwa semua peserta pelatihan mengetahui berita. Pada topik menulis berita cuma 5 peserta yang sudah pernah menulis, sementara 25 belum pernah melakukan menulis berita, namun demikian minat untuk belajar menulis berita sangat antusias. Kemauan untuk belajar menulis berita ini seluruh peserta menyanggupi. Peserta juga tidak mengetahui apa sebenarnya esensi menulis berita dan manfaatnya, sebanyak 10 orang mengetahui, sementara 20 peserta belum mengetahui.

Untuk lebih mendalam mengetahui terkait menulis berita dan manfaatnya, dilakukan juga posttest. Dari hasil post-test menunjukkan perbedaan yang signifikan dibandingkan hasil pretest. Berikut tabelnya:

\begin{tabular}{|l|c|c|c|c|}
\hline \multicolumn{5}{|c|}{ POSTEST } \\
\hline $\mathbf{N}$ & Topik Test & Ya & Tidak & Ragu- \\
\hline
\end{tabular}

\begin{tabular}{|c|c|c|c|c|}
\hline o & & & & ragu \\
\hline 1 & $\begin{array}{l}\text { Pengenalan } \\
\text { berita }\end{array}$ & 30 & 0 & 0 \\
\hline 2 & $\begin{array}{l}\text { Mencoba } \\
\text { menulis } \\
\text { berita }\end{array}$ & 30 & 0 & 0 \\
\hline 3 & $\begin{array}{l}\text { Kemauan } \\
\text { menulis } \\
\text { berita }\end{array}$ & 30 & 0 & 0 \\
\hline 4 & $\begin{array}{l}\text { Keuntunga } \\
\mathrm{n} \text { menulis } \\
\text { berita }\end{array}$ & 30 & 0 & 0 \\
\hline 5 & \multicolumn{4}{|c|}{$\begin{array}{l}\text { Keuntungan menulis berita: } \\
\text { a. Peluang Bisnis } \\
\text { b. Dapat mengabarkan } \\
\text { kegiatan } \\
\text { c. Menambah wawasan } \\
\text { d. Berbagi informasi } \\
\text { e. Mendapat ilmu } \\
\text { f. Publikasi tulisan } \\
\text { g. Promosi }\end{array}$} \\
\hline
\end{tabular}

Berdasarkan tabel di atas, dapat dijelaskan bahwa topik pengenalan istilah berita, keinginan belajar menulis berita, sebagian besar peserta menjawab "ya". Hal ini membuktikan bahwa sebagian besar peserta memiliki kemauan untuk menulis, namun kendala utamanya adalah peserta belum

Pendidikan 733 
mengenal dan mengetahui manfaat menulis berita.

\section{Bagi peserta yang}

mengetahui keuntungan menulis berita, mereka mencatat terdapat beberapa penambahan pengetahuan dalam menulis berita, yaitu pada jawaban promosi dan ladang mencari penghasilan.

Merujuk dari hasil isian pretest dan posttest dapat ditarik simpulan, bahwa pelatihan ini cukup disambut antusias oleh peserta,.Selain ilmu yang didapat, peserta juga memiliki keterampilan untuk menulis berita yang dimanfaatkan untuk bertukar informasi, memperoleh pengetahuan, media berekspresi, bahkan sebagai promosi kegiatan dan memperoleh penghasilan.

\section{Luaran yang Dicapai}

Luaran yang dicapai dalam kegiatan ini adalah tulisan berita dan draft artikel ilmiah. Draft artikel ilmiah terlampir pada Lampiran Artikel Ilmiah. Sedangkan untuk produk menulis berita belum semua peserta mampu menghasilkan berita.

\section{UCAPAN TERIMA KASIH}

Penulis ucapkan terimakasih kepada Rektor Universitas Lancang Kuning yang telah memberikan dukungan melalui LPPM berupa pengawasan terhadap keberlangsungan program ini. Penulis juga mengucapkan terimakasih kepada pihak Fakultas Ilmu Budaya Universitas Lancang Kuning selaku penyedia dana demi kelancaran program ini. Penulis juga mengucapkan terimakasih kepada semua pihak, yang tidak dapat disebut satu-persatu di sini, yang telah membantu dalam pelaksanaan program pengabdian kepada masyarakat ini. Akhirnya semoga hasil pengabdian ini dapat bermanfaat bagi penulis dan dunia akademis khususnya serta masyarakat pada umumnya.

\section{SIMPULAN DAN SARAN}

\section{Simpulan}

Dari pelatihan ini dapat disimpulkan bahwa banyak generasi muda, khususnya siswa SMA Negeri 16 Pekanbaru berminat dan memiliki kemampuan menulis berita. Namun karena pelatihan ini terbatas, maka belum menghasilkan hasil yang Pendidikan 734 
maksimal. Walaupun demikian, paling tidak pelatihan ini menjadi tahap awal mengenalkan arti penting menulis berita.

\section{Saran}

Banyak peserta menghendaki pelatihan menulis berita rutin dilaksanakan, sehingga mereka dapat memehami dan mengetahui manfaat menulis berita ini. Untuk itulah, dari pelatihan ini, kami menyarankan FIB Unilak membentuk badan atau tim kreatif "rumah menulis" bagi generasi muda, terutama siswa SMA.

\section{REFERENSI}

Arswendo Atmowiloto. 2004. Mengarang Itu Gampang. Jakarta: Gramedia Pustaka Utama

Keraf, Gorys. 1997. Komposisi Sebuah Pengantar Kemahiran Bahasa. Ende: Penerbit Nusa Indah

Mohamad Diponegoro. 1985. Cara Menulis Berita. Jakarta: SP

Winna Efendi. 2012. Taktik Menulis. Jakarta: Gagas Media 